\title{
A generic RNA-pulsed dendritic cell vaccine strategy for renal cell
} carcinoma

\author{
Christiane Geiger $^{\dagger 1}$, Sybille Regn ${ }^{\dagger 1}$, Andreas Weinzierl ${ }^{2}$, Elfriede Noessner ${ }^{1}$ \\ and Dolores J Schendel*1
}

Address: ${ }^{1}$ Institute of Molecular Immunology, GSF-National Research Center for Environment and Health, Munich, Germany and ${ }^{2}$ Institute of Cell Biology, Department of Immunology, University of Tübingen, Tübingen, Germany

Email: Christiane Geiger - christiane.geiger@gsf.de; Sybille Regn - Sybille_Regn@hotmail.com; Andreas Weinzierl - andreas.weinzierl@unituebingen.de; Elfriede Noessner - noessner@gsf.de; Dolores J Schendel* - schendel@gsf.de

* Corresponding author †Equal contributors

Published: 26 July 2005

Journal of Translational Medicine 2005, 3:29 doi:10.1 186/1479-5876-3-29
Received: II May 2005

Accepted: 26 July 2005

This article is available from: http://www.translational-medicine.com/content/3/I/29

(c) 2005 Geiger et al; licensee BioMed Central Ltd.

This is an Open Access article distributed under the terms of the Creative Commons Attribution License (http://creativecommons.org/licenses/by/2.0), which permits unrestricted use, distribution, and reproduction in any medium, provided the original work is properly cited.

\begin{abstract}
We present a generic dendritic cell (DC) vaccine strategy for patients with renal cell carcinoma (RCC) based on the use of RNA as a source of multiplex tumor-associated antigens (TAAs). Instead of preparing RNA from tumor tissue of each individual RCC patient, we propose to substitute RNA prepared from a well characterized highly immunogenic RCC cell line (RCC-26 tumor cells) as a generic source of TAAs for loading of DCs. We demonstrate here that efficient RNA transfer can be achieved using lipofection of immature DCs, which are subsequently matured with a cytokine cocktail to express high levels of MHC and costimulatory molecules as well as the chemokine receptor CCR7. Neither RNA itself nor the lipid component impacted on the phenotype or the cytokine secretion of mature DCs.

Following RNA loading, DCs derived from HLA-A2-positive donors were able to activate effectormemory cytotoxic T lymphocytes (CTLs) specific for a TAA ligand expressed by the RCC-26 cell line. CTL responses to RNA-loaded DCs reached levels comparable to those stimulated directly by the RCC-26 tumor cells. Furthermore, DCs expressing tumor cell RNA primed naïve T cells, yielding $T$ cell lines with cytotoxicity and cytokine secretion after contact with RCC tumor cells. RCC-26 cell lines are available as good manufacturing practice (GMP)-certified reagents enabling this source of RNA to be easily standardized and adapted for clinical testing. In addition, well defined immune monitoring tools, including the use of RNA expressing B cell lines, are available. Thus, this DC vaccine strategy can be directly compared with an ongoing gene therapy trial using genetically-engineered variants of the RCC- 26 cell line as vaccines for RCC patients with metastatic disease.
\end{abstract}

\section{Background}

Renal cell carcinomas (RCC) are classified as immuno- genic tumors based on the observation that patients with metastatic RCC show some of the most favorable 
responses to immunotherapy [reviewed in $[1,2]]$; tumorinfiltrating lymphocytes (TIL) have been isolated that kill autologous tumor cells following restimulation in vitro [reviewed in [3]] and adoptive transfer of TIL provided clinical benefit to some RCC patients [4-7]. It would be desirable to exploit these reservoirs of effector cells in RCC patients in order to improve antitumor immunity. This could be achieved either by vaccinating patients to boost pre-existing cellular immunity or by using adoptive transfer of specific effector cells that have been activated and expanded ex vivo.

Applying specific antigens for these purposes has been hindered in RCC by a paucity of information regarding the identity of tumor-associated antigens (TAAs) that can serve as effective tumor rejection antigens. For example, members of the cancer-germline family, like NY-ESO-1 molecules and several members of the MAGE family which display suitable characteristics as immunogens for other tumors, are not expressed in the majority of RCC [812]. Therefore, vaccine developments for RCC have concentrated to date on the use of tumor cells themselves to provide mixtures of unknown TAAs as immunogens. On this basis, several types of autologous RCC vaccination strategies have been evaluated in clinical trials, including the use of inactivated tumor cells, gene-modified tumor cells or DCs expressing antigens derived from RCC lysates, tumor-RNA or following fusion with autologous tumor cells [reviewed in [13]]. While these approaches were found to be feasible, demonstrated limited toxicity, and showed some bioactivity and clinical impact, long-term vaccination was hindered by the lack of adequate amounts of tumor from many patients. To overcome this limitation, alternative strategies using allogeneic tumor cell lines can be employed, whereby development of effective antitumor immunity relies on the presence of target molecules that are shared among various RCC. CTL recognition studies and molecular profiling of tumor cells support the validity of this contention for RCC [14-22].

We developed an allogeneic tumor cell vaccine using a well characterized tumor line (RCC-26) that was derived from a patient with early stage disease (T1, N0, M0). Studies of autologous and allogeneic TIL demonstrated that this RCC line displayed a number of distinct peptidemajor histocompatibility complex (pMHC) ligands, some of which were restricted by HLA-A*0201-encoded molecules and shared by other RCCs. Autologous TIL-26 cells recognized their specific pMHC ligands on RCC- 26 cells but not on cells derived from normal kidney parenchyma (NKC-26) or Epstein- Barr virus-transformed lymphoblastoid cells (LCL-26) [14], revealing their tumor-associated specificity. We genetically engineered RCC-26 cells to express CD80 together with selected cytokines in order to enhance their natural immunogenicity and we have initi- ated a two-center trial comparing vaccine variants expressing CD80 with IL-2 or IL-7 in HLA-A*0201-matched patients with metastatic disease $[13,23]$.

While this allogeneic approach has the advantage that vaccines can be derived from well charcterized tumor cells and a generic source of vaccine can be used in multiple patients, it is limited by the fact that immunization may only be optimally effective in patients who are partially matched for HLA allotypes with the vaccine cells, since encounter with DCs allowing cross-presentation of TAAs may not be very efficient in vivo. Furthermore, if the vaccine cell is the direct APC for T cell stimulation, responses are limited to $\mathrm{CD}^{+} \mathrm{T}$ cells because the RCC cells do not express MHC class II molecules.

To overcome this limitation and allow patients with various HLA allotypes to be entered into clinical trials, the development of a vaccine using autologous DCs loaded with tumor-derived RNA represents a promising new approach [24]. We reasoned that RNA derived from our well characterized RCC- 26 cell line could be used not only as a source of multiplex TAAs, but also could serve as a tool for post-vaccination immune monitoring. Here we report our strategy for the development of a generic RNApulsed DC vaccine and the characterization of DCs loaded with RCC-derived RNA.

\section{Methods}

\section{Cell lines and cultures}

The renal cell carcinoma cell line RCC-26 was established from a primary stage I (T1, N0, M0, G2) clear cell carcinoma of patient-26, as described previously [14] (HLA alleles: A*0201, A*3303, B*4101, B*5101, Cw*1502 and $\left.\mathrm{Cw}^{*} 1701\right)$. The RCC- 53 cell line was generated similarly from a second patient (T2, N1, M1, G2-3) with clear cell carcinoma (HLA alleles: A*0201, A*2501, B*1501, $\mathrm{B}^{*} 1801, \mathrm{Cw}^{*} 1203$ and $\mathrm{Cw}^{*} 0303$ ) [25]. Epstein-Barr virus (EBV)-transformed lymphoblastoid cell lines (LCLs) were generated as described [26]. All cell lines were cultured in RPMI 1640 medium supplemented with $12 \%$ fetal bovine serum (FBS), $2 \mathrm{mM}$ L-glutamine, $1 \mathrm{mM}$ sodium pyruvate and $1 \times$ non-essential amino acids. The TIL- 26 cell line was obtained from the primary tumor of patient-26 as published [14], cultured in RPMI 1640 medium containing $7.5 \%$ FBS, 7.5\% heat-inactivated, pooled human serum, 2 $\mathrm{mM}$ L-glutamine, $1 \mathrm{mM}$ sodium-pyruvate and $1 \times$ nonessential amino acids and restimulated every 14 days with irradiated autologous tumor cells.

\section{Generation of monocyte-derived DCs from peripheral blood mononuclear cells}

Peripheral blood mononuclear cells (PBMCs) were isolated by standard Ficoll-Paque (PAN Biotech, Aidenbach, Germany) density gradient centrifugation of heparinized 
blood obtained from healthy donors and washed twice in PBS. Subsequently, CD14+ cells were affinity purified utilizing the magnetic cell sorting kit (MACS) (Miltenyi Biotec, Bergisch Gladbach, Germany), according to the manufacturer's instructions. In brief, the isolated PBMCs were incubated with CD14 MicroBeads in a concentration of $15 \mu \mathrm{l} / 10^{7}$ PBMCs in PBS containing $1 \%$ FBS at $4{ }^{\circ} \mathrm{C}$ for $15 \mathrm{~min}$. The labelled cells were washed once, passed through a positive selection column, washed three times and eluted from the column. To generate DCs, the CD14+ cells were cultured in X-Vivo 15 medium (Cambrex Bio Science, Verviers, Belgium) supplemented with $800 \mathrm{U} / \mathrm{ml}$ rhuGM-CSF (Leukine, Berlex, Richmond, USA) and 10 ng/ml rhulL-4 (Promocell Bioscience, Heidelberg, Germany) at a cell concentration of $1.5 \times 10^{6} / \mathrm{ml}$ in 6-well culture plates (TPP, Peske, Aindling, Germany). For maturation of immature DCs (iDCs), the cells were incubated on day 6-7 with a cytokine cocktail containing $250 \mathrm{U} / \mathrm{ml}$ rhuTNF- $\alpha, 20 \mathrm{ng} / \mathrm{ml}$ rhuIL-1 $\beta$ (Promocell Bioscience), 1 $\mu \mathrm{M}$ PGE2 (Sigma, Taufkirchen, Germany) and $1000 \mathrm{U} / \mathrm{ml}$ rhuIL-6 (R\&D Systems, Minneapolis, USA) for 48 h [27]. Additionally, the cultures were supplemented with $800 \mathrm{U} /$ $\mathrm{ml}$ rhuGM-CSF and $10 \mathrm{ng} / \mathrm{ml}$ rhuIL-4.

\section{Isolation of total tumor RNA}

Total tumor RNA was extracted from the human RCC cell lines, RCC-26 and RCC- 53, using Tri Reagent ${ }^{\circledR}$ (Sigma) according to the manufacturer's instructions.

\section{Generation of in vitro-transcribed mRNA}

In vitro-transcribed enhanced green fluorescent protein (EGFP) mRNA was prepared using the vector pGEM4Z/ GFP/A64 [28] (kindly provided by E. Gilboa, The Center for Cellular and Genetic Therapies, Duke University Medical Center, Durham, NC, USA), which already contained the poly(A) template. In vitro transcription under the control of a T7 promoter was carried out using the mMESSAGE mMACHINE ${ }^{\mathrm{TM}}$ T7 kit (Ambion, Austin, Texas, USA). IVT mRNA was then purified using the RNeasy Mini Kit (Qiagen, Hilden, Germany) following the RNA cleanup protocol.

\section{Transfection of DCs}

Transfection of DCs with RNA was carried out using the cationic lipid reagent DMRIE-C (Invitrogen, Karlsruhe, Germany). On day 7, iDCs were harvested and resuspended in OptiMEM ${ }^{\oplus}$ (Invitrogen) at a final concentration of $1.0 \times 10^{6} \mathrm{DCs} / \mathrm{ml}$. This cell suspension was distributed immediately in 24 -well plates $(0.5 \mathrm{ml} /$ well $=$ $0.5 \times 10^{6} \mathrm{iDCs} /$ well). The RNA/lipid solution was prepared as follows: for each DC culture well $0.5 \mathrm{ml}$ OptiMEM $^{\circledast}$ I was mixed with $5 \mu$ l DMRIE-C in a polystyrene tube and the desired amount of RNA was subsequently added to the mixture. In general, $2.5-5.0 \mu \mathrm{g}$ of IVT mRNA or $5.0 \mu \mathrm{g}$ of total tumor RNA were applied for transfection of $0.5 \times 10^{6}$ iDCs. The RNA/lipid solution was transferred immediately to the iDCs. After a $4 \mathrm{~h}$ incubation period at $37^{\circ} \mathrm{C}$, the transfection solution was removed and replaced by X-VIVO 15, supplemented with the cytokine cocktail for DC maturation as indicated.

\section{Flow cytometric analysis}

Phenotypic analysis of DCs was carried out by immunofluorescence staining of dendritic-monocyte differentiation and activation markers. Cells were labelled with mouse monoclonal antibodies (mabs) either unconjugated or directly conjugated with fluorescein isothiocyanate (FITC) or phycoerythrin (PE). The following FITCconjugated mabs were used: anti-HLA-DR (IgG2a, clone G46-6), anti-CD83 (IgG1, clone HB15e), anti-DC-SIGN (IgG2b, clone DCN46), anti-CD14 (IgG2a, clone M5E2) (BD Pharmingen, San Diego, USA). The following mabs were used as PE-conjugated reagents: anti-CD86 (IgG1, clone 2331 FUN-1), anti-CD80 (IgG1, clone L307.4) (BD Pharmingen), anti-CD40 (IgG1, clone mAb89) (Beckman Coulter, Krefeld, Germany). Clone 2H4 specific for human CCR7 (BD Pharmingen) was unconjugated. Indirect immunofluorescence was performed using monoclonal biotin-conjugated rat-anti-mouse IgM (clone II/41) in combination with PE-conjugated streptavidin (BD Pharmingen). PE/FITC isotype-matched mouse immunoglobulins were used as negative controls (BD Pharmingen).

Cells were washed once with PBS containing 1\% FBS and incubated with the appropriate mab for $30 \mathrm{~min}$ on ice in $\mathrm{PBS} / 1 \% \mathrm{FBS}$. Then cells were washed once again and fixed in $\mathrm{PBS} / 1 \%$ paraformaldehyde. Samples were acquired using a FACSCalibur instrument (BD Bioscience Immunocytometry Systems, San Jose, USA) and data analysis was performed using CellQuest Pro software. For determination of EGFP expression, DCs were harvested approximately $24 \mathrm{~h}$ after transfection, washed once and directly analyzed by flow cytometry.

\section{Analysis of cytokine expression}

Release of cytokines by DCs was measured using the highly sensitive Bio-Plex human cytokine reagent kit (BioRad Laboratories Inc., Hercules, CA, USA), according to the manufacturer's protocol. Data analysis was performed using the BioRad Array Operation System (BioRad) and applied five parameter logistic regression algorithms.

\section{T cell stimulation assay}

Stimulating cells were harvested and plated in triplicates in 96-well U-bottomed plates at a concentration of $1.5 \times$ $10^{4}$ cells per well in $100 \mu \mathrm{l}$ of the appropriate T cell media. $\mathrm{T}$ cells were added in a concentration of 3000 cells/well (in the case of the TIL-26(GG) clone) or $1.5 \times 10^{4}$ cells/ well (in the case of de novo primed T cell lines) in $100 \mu \mathrm{l}$, 
yielding a total volume of $200 \mu \mathrm{l} /$ well. Culture supernatants were harvested after a $24 \mathrm{~h}$ incubation period at $37^{\circ} \mathrm{C}$ and release of interferon-gamma (IFN $\gamma$ ) was measured using a commercially available enzyme-linked immunosorbent assay (BD Pharmingen).

\section{T cell priming}

The generation of antitumor $\mathrm{T}$ cell lines was carried out using autologous cells derived from blood of healthy volunteers. Monocyte-derived iDCs were transfected with total tumor RNA, as described above and matured for 48 h. In 24 -well plates, $1.25 \times 10^{5} \mathrm{mDCs}$ were incubated with $1 \times 10^{6}$ autologous PBMCs in a total volume of $2 \mathrm{ml} /$ well in RPMI 1640 medium containing 12\% heat inactivated, pooled human serum, $2 \mathrm{mM}$ L-glutamine, $1 \mathrm{mM}$ sodiumpyruvate and $1 \times$ non-essential amino acids. After 10-12 days of culture, cells were restimulated with autologous mDCs transfected with total cellular RNA in a ratio of 4:1 (PBMC:mDC). Subsequent rounds of restimulation were carried out in an analogous manner, replacing stimulator DCs every 7 days. $10 \mathrm{ng} / \mathrm{ml}$ rhulL-7 (Promocell Bioscience) and $20 \mathrm{U} / \mathrm{ml}$ rhulL-2 (Proleukine ${ }^{\circledast}$, Chiron, Emeryville, CA, USA) were added to the culture three times per week starting at days 12 and 18, respectively. The cytolytic activity of induced CTLs was analyzed on day 4 after the last round of restimulation in a standard ${ }^{51}$ chromium-release assay. Release of IFN $\gamma$ following $\mathrm{T}$ cell stimulation was measured on day 10 after the last round of restimulation, using a commercially available enzymelinked immunosorbent assay (BD Pharmingen).

\section{IChromium-release assay}

Cell-mediated lysis was measured in a standard ${ }^{51} \mathrm{Cr}-$ release assay as described earlier [29]. In brief, target cells were labelled with $\mathrm{Na}_{2}{ }^{51} \mathrm{CrO} 4$ (Hartmann Analytic, Braunschweig, Germany) at $37^{\circ} \mathrm{C}$ for $1 \mathrm{~h}$ and co-cultured with the effector cells at the indicated effector:target (E:T) cell ratios in a 96-well V-bottomed plate for $4 \mathrm{~h}$. Spontaneous ${ }^{51} \mathrm{Cr}$-release was obtained by incubating target cells alone and maximum release by directly counting labelled cells only. The percentage of specific lysis was calculated as: $100 \times($ experimental counts per minute $(\mathrm{cpm})$ - spontaneous cpm) / (maximal cpm - spontaneous cpm). Triplicate measurements of four-step titrations of effector cells were used for the experiments.

\section{Results}

\section{Strategy for a generic RNA-pulsed DC vaccine for RCC patients}

We foresee the following strategy for the development and application of a generic RNA-pulsed DC vaccine for RCC (Figure 1). In a first step, PBMCs from a metastatic RCC (mRCC) patient are isolated before treatment to acquire monocytes (Step 1a) and to generate autologous EBVtransformed LCLs for long-term studies (Step 1b). In a sec- ond step, the isolated monocytes are differentiated into immature dendritic cells (iDCs) in the presence of GMCSF and IL-4 (Step 2). On day 7 of culture, iDCs are transfected with total RNA derived from the RCC-26 cell line and subsequently matured using a defined pro-inflammatory cytokine cocktail for $48 \mathrm{~h}$ (Step 3).

The application of RNA derived from an established and well characterized RCC cell line comprises the generic component of this approach. Total RNA is isolated from this cell line, providing a virtually unlimited source of TAAs. This bypasses the need for RNA preparation from, often limited, individual patient tumor tissues. Fully matured DCs, loaded with generic RNA can than be applied for vaccination of mRCC patients (Step 4).

The autologous LCLs are instrumental for analysing the activation, expansion and perseverance of specific $\mathrm{T}$ cell responses after vaccination. Transfection of autologous LCLs with RCC-derived RNA (Step 5) will generate APCs expressing different pMHC complexes with various TAA epitopes. By co-cultivating these APCs with autologous post-treatment PBMCs, under limiting dilution culture conditions, it should be possible to track the development of both MHC class I and class II-restricted T cells contributing to antitumor immunity (Step 6). Either RCC-26derived RNA or single-species RNAs corresponding to individual TAAs expressed by RCC-26 cells [23] can be employed to potentially identify the fine specificity of emerging $\mathrm{T}$ cell responses.

\section{Immature DCs can be efficiently transfected with in vitro transcribed mRNA using lipofection}

Steps 1 and 2 of the strategy described above are standard procedures nowadays. In our studies, the generation of monocyte-derived iDCs in the presence of GM-CSF and IL-4 yielded considerable cell numbers (approximately $50 \%$ of the isolated monocytes) and subsequent activation of the iDCs could be achieved by stimulation with a pro-inflammatory cytokine cocktail (TNF- $\alpha$, IL- $1 \beta$, PGE $_{2}$ and IL-6) for $48 \mathrm{~h}$ [26]. This activation resulted in fully mature DCs (mDCs) showing high expression of maturation and activation markers, like CD86, CD80, CD83, CD40 and the chemokine receptor CCR7. In contrast, the monocyte marker CD14 was completely down-regulated (Fig. 2).

Different techniques are discussed in the literature for loading DCs with RNA (Step 3) [30-36] but the optimal procedure for generating fully immunocompetent RNAexpressing DCs for in vivo application still has to be defined. In our studies, we utilized the method of lipofection to load DCs with tumor-derived RNA. To quantify the efficiency of RNA transfection, iDCs were lipofected with in vitro-transcribed EGFP mRNA using the transfection 


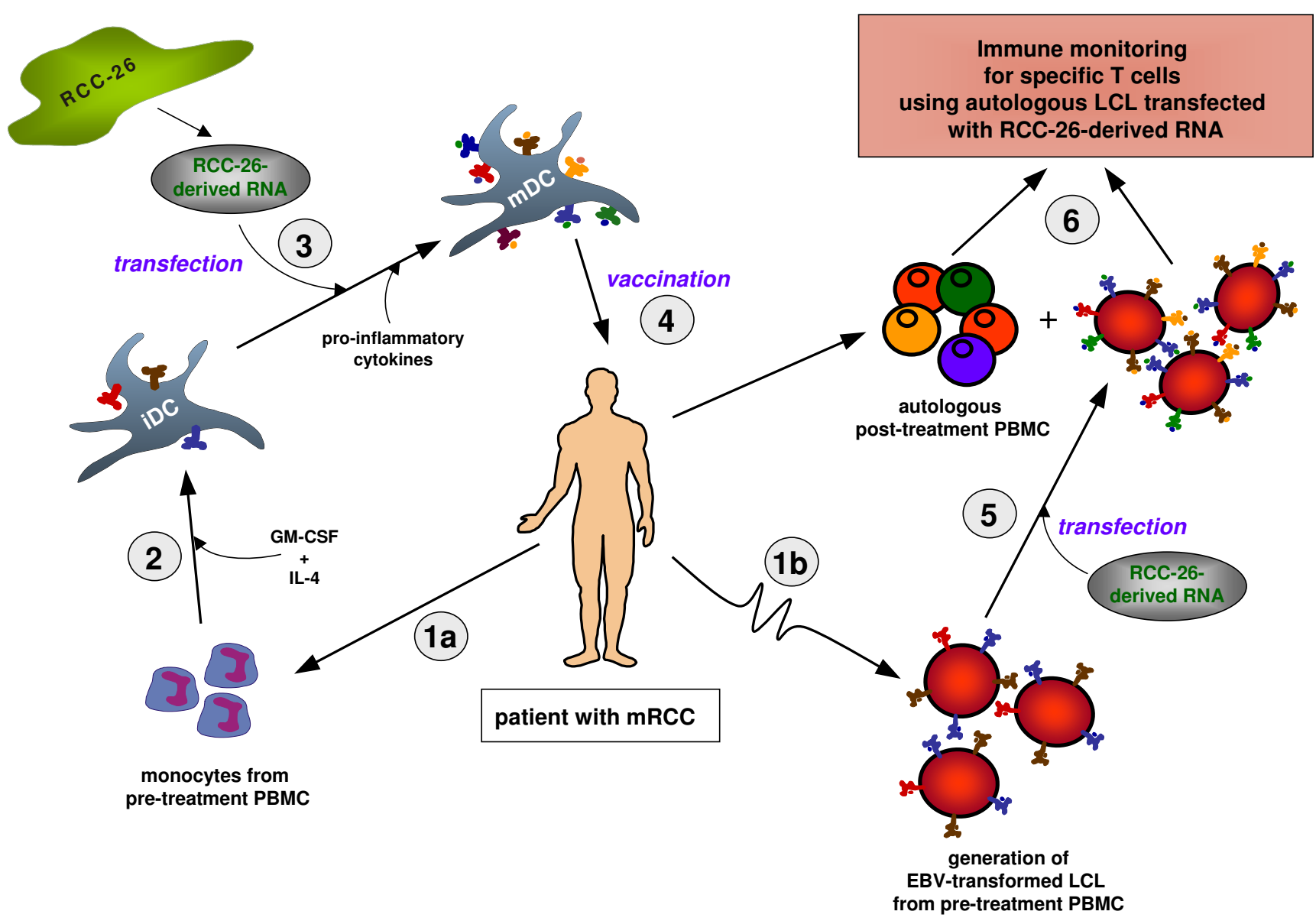

Figure I

Strategy for a generic RNA-pulsed DC vaccine for metastatic renal cell carcinoma. See text for detailed explanation.

reagent DMRIE-C at day 7 of culture. DMRIE-C was chosen since it showed the lowest toxicity and highest transfection efficiency compared to other transfection reagents, such as DOTAP and TransFast (data not shown). Flow cytometric analysis of EGFP expression $48 \mathrm{~h}$ post-transfection revealed an average transfection rate of $20-40 \%$, depending on the conditions chosen (Fig. 3).

In addressing the question whether subsequent maturation of transfected DCs had an impact on protein expression, we found an increase in EGFP-positive cells when transfected DCs $\left(2.5 \mu \mathrm{g}\right.$ mRN/0.5 $\times 10^{6}$ cells $)$ were exposed to the maturation cocktail for $48 \mathrm{~h}$ (Fig. 3A). The lipofection efficiency could also be enhanced by application of increasing amounts of EGFP mRNA. For example, the use of $5.0 \mu \mathrm{g}$ mRNA/ $0.5 \times 10^{6}$ cells increased the percentage of positive cells by $10 \%$ compared to $2.5 \mu \mathrm{g}$ mRNA (Fig. 3B). In all cases, lipofection of mRNA resulted in a broad range of protein density, generating
DCs with EGFP protein expression ranging from low to very high levels (Fig. 3A, B and 3C).

\section{Lipofection of DCs with RNA does not adversely interfere with cell maturation}

Since we were interested to know whether RNA lipofection of iDCs interfered with DC maturation, we co-incubated the transfected iDCs with the different lipofection components (lipid + RNA), with or without maturation cytokine cocktail, and analyzed the DC phenotype by flow cytometry $48 \mathrm{~h}$ later. Incubation of iDCs with lipid plus RNA had no significant impact on DC maturation (Fig. 4, two left panels). A fully mature DC phenotype could only be induced by incubation with the pro-inflammatory cytokine cocktail, resulting in high expression of CD40 and up-regulation of CD86 and CD83 expression. Also, expression of the chemokine receptor CCR7, which is crucial for the migration of DCs to secondary lymphoid 


\section{HLA-DR}

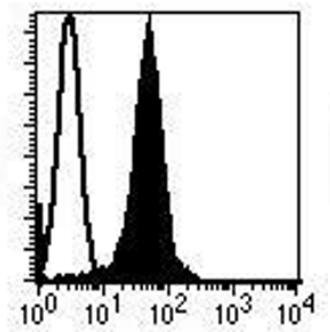

CD86

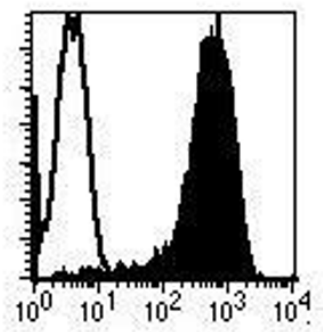

CD80

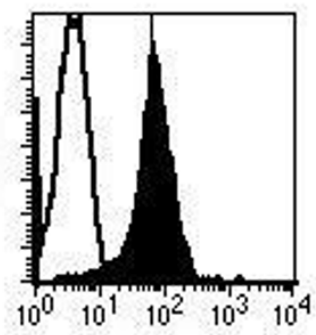

CD83

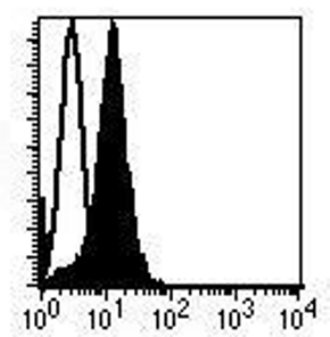

DC-SIGN

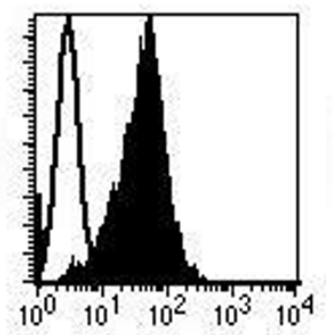

CD40

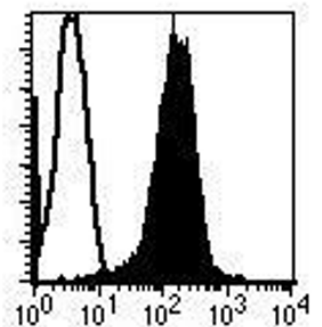

CCR7

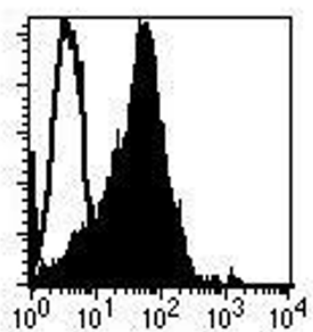

CD14

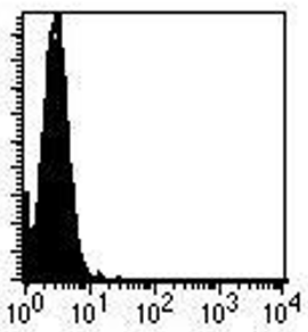

\section{Mean Fluoresence Intensity}

Figure 2

Phenotype of mature DCs. The incubation of monocyte-derived iDCs with a pro-inflammatory cytokine cocktail composed of IL-I $\beta$, IL-6, TNF- $\alpha$ and PGE $E_{2}$ for $48 \mathrm{~h}$ induced a fully mature DC phenotype. Status of maturation was measured by staining of different DC maturation and activation markers followed by flow cytometric analysis.

organs [37-40], was significantly up-regulated only after cytokine-induced maturation of the DCs (Fig. 4, two right panels).

Additionally, we analyzed the cytokines secreted by the DCs in order to determine whether loading of iDCs with RNA altered their cytokine production capacity. We tested supernatants of differentially treated DCs using a cytokine multiplex panel. On day 7 of culture, iDCs were incubated with the different components (lipid alone, RNA alone or RNA in combination with lipid). Subsequently, DCs were either matured or kept in the immature stage for $48 \mathrm{~h}$ before supernatants were harvested and analyzed. IL12p70 was detected at low levels while IL-10 and IL-2 were detected in slightly higher amounts, but neither the applied RNA nor the lipofection reagent showed any significant impact on the levels of cytokines secreted by iDCs or mDCs. In general, maturation of DCs led to an increased secretion of these three cytokines (data not shown).

\section{Specific effector-memory CTLs can be activated by DCs lipofected with tumor cell line-derived RNA}

DCs applied for vaccination (Fig. 1, Step 4) must be competent to stimulate specific immune responses. To evaluate the specific immunostimulatory potential of RNAloaded DCs for effector-memory CTLs, iDCs derived from HLA-A*0201-positive healthy donors were transfected on day 7 with total RNA prepared from the tumor line RCC26 using lipofection (5.0 $\mu \mathrm{g}$ RNA/0.5 $\left.\times 10^{6} \mathrm{DCs}\right)$. 
A
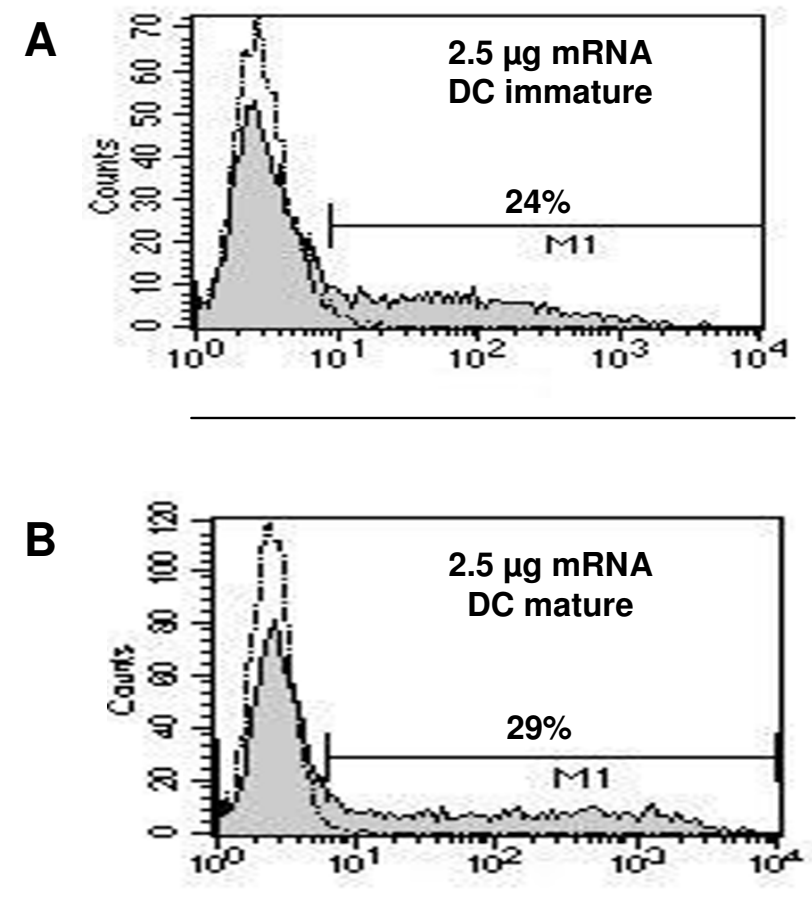

B

\section{EGFP}

C

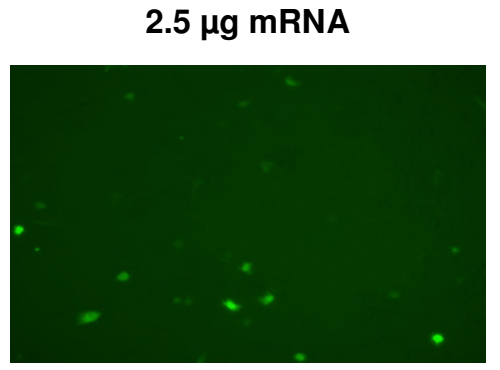

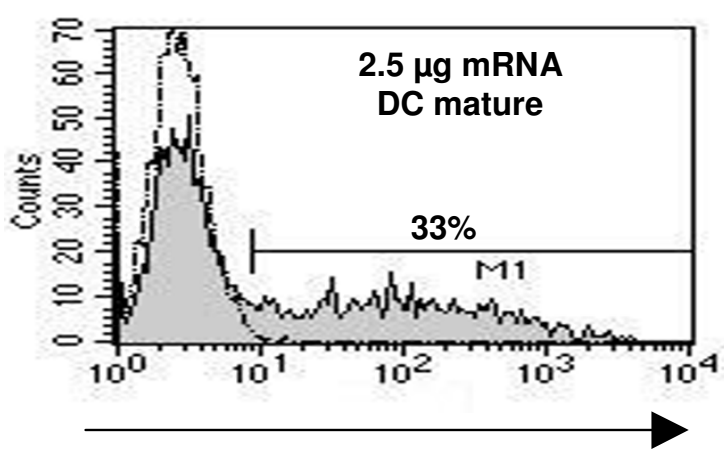

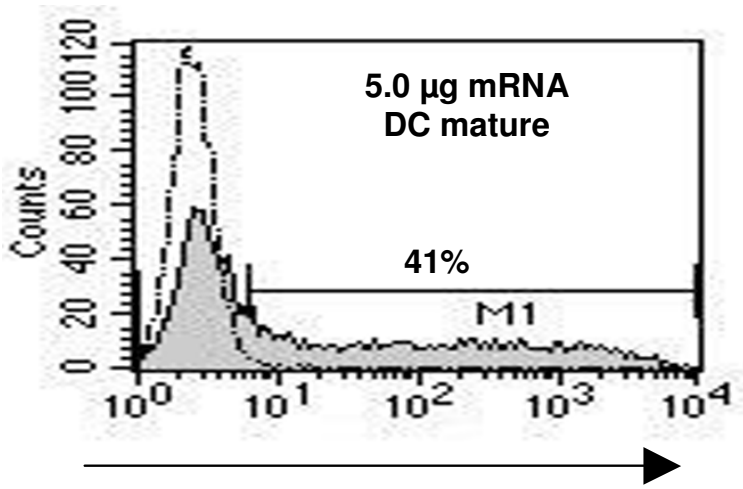

$5 \mu g$ mRNA

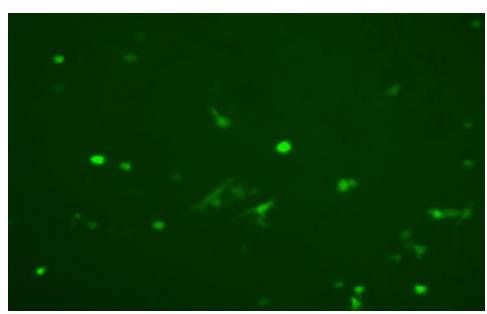

\section{Figure 3}

Transfection of immature DCs with EGFP mRNA. iDCs were transfected by lipofection using DMRIE-C and in vitro-transcribed EGFP mRNA. A) $2.5 \mu \mathrm{g}$ EGFP mRNA/0.5 $\times 10^{6} \mathrm{iDCs}$ were transfected and the DCs were kept either as immature cells or matured using a cytokine cocktail. B) $2.5 \mu \mathrm{g}$ and $5.0 \mu \mathrm{g}$ EGFP mRNA/0.5 $\times 10^{6} \mathrm{iDCs}$, respectively, were transfected and the DCs matured. EGFP expression was analyzed by flow cytometry $48 \mathrm{~h}$ after transfection (grey histograms). DCs transfected with $\mathrm{H}_{2} \mathrm{O}$ only were used as a control (broken line). C) EGFP-expression in transfected DCs was visualized using a fluorescent microscope.

Following transfection, DCs were matured for $48 \mathrm{~h}$. On day 9, transfected DCs were co-cultivated with TIL-26 cells. TIL-26 line is a tumor antigen-specific CTL line that was expanded from the tumor-infiltrating lymphocyte population of patient-26 and was demonstrated to recognize a RCC-26-associated determinant presented by HLA$\mathrm{A}^{*}$ 0201-encoded molecules [14]. The TIL-26-derived clone, TIL-26(GG) [41] was employed for all experiments. 
Immature DCs
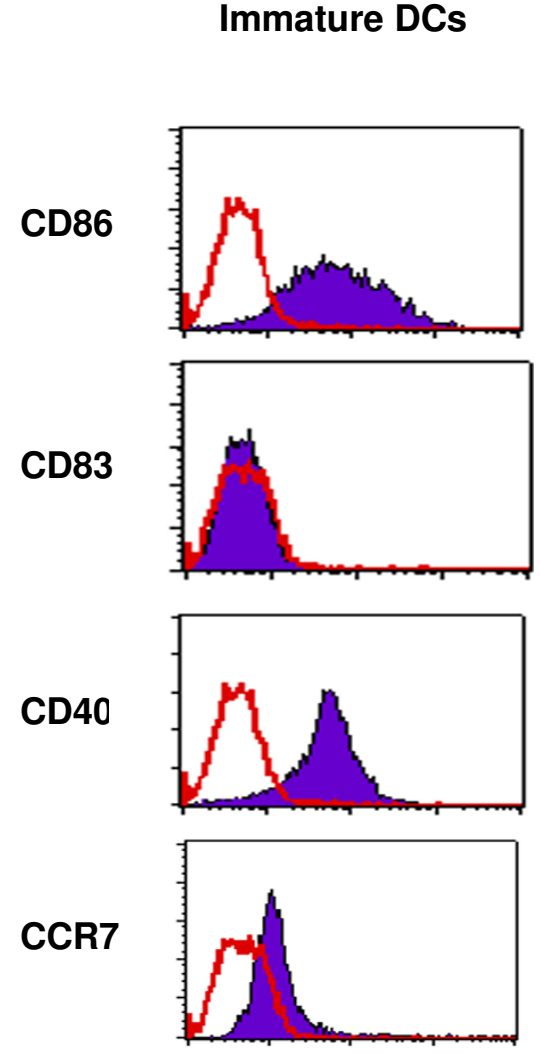

\section{Immature DCs} +Lipid +RNA
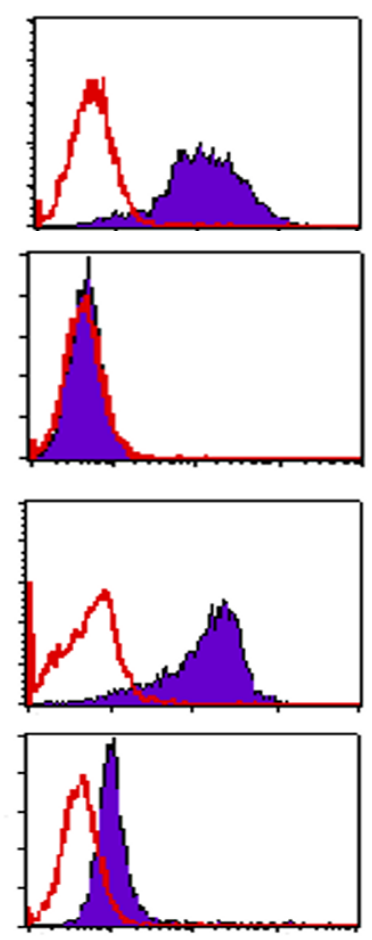

Mature DCs
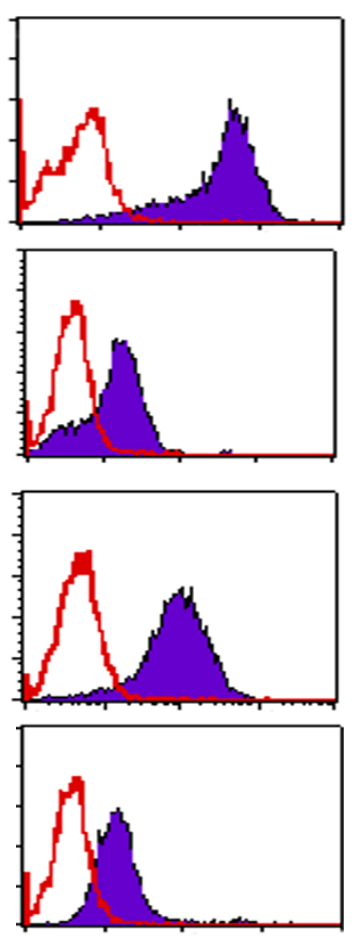

Mature DCs +Lipid +RNA
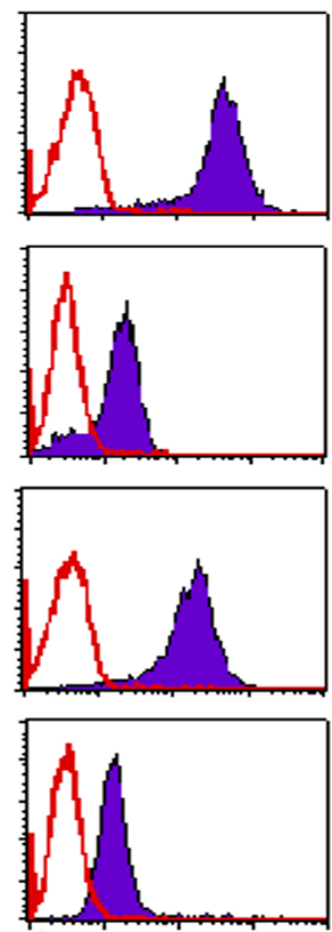

\section{Mean Fluorescence Intensity}

\section{Figure 4}

Lipofection of DCs with RNA does not adversely affect their phenotype. iDCs were incubated with DMRIE-C plus RNA, as described in the Methods section. After a $4 \mathrm{~h}$ incubation, the DCs were either kept immature or matured using a cytokinecocktail. The DC phenotype was analyzed by flow cytometry $48 \mathrm{~h}$ after transfection.

After a $24 \mathrm{~h}$ incubation period, the supernatants of TIL26(GG) co-cultured with DCs were harvested and assessed for IFN $\gamma$ in a standard ELISA assay.

To demonstrate specificity, the TIL-26(GG) clone was cocultivated with different cell lines. Only co-culture with RCC-26 cells, but not with autologous LCL-26, the normal kidney cell line (NKC-26), or the HLA-A*0201matched tumor cell line RCC-53 induced IFN $\gamma$-release, indicating that only RCC- 26 cells provided the specific ligand for TIL-26 activation (Figure 5A). Furthermore, TIL26(GG) had no LAK or NK activitiy directed against Daudi or K562 cells. DCs transfected with the RCC-26-derived RNA, but not DCs alone, were able to induce IFN $\gamma$-secretion in TIL-26(GG) cells, indicating that the RCC-26derived RNA was also capable of providing the TIL-26specific epitope to the DCs. DCs transfected with RNA derived from RCC-53 or LCL-26, both of which are HLAA2-positive cell lines that do not express the TIL-26 epitope (Fig. 5A), were not recognized by the T cell clone, further confirming the specificity of the $\mathrm{T}$ cell activation by RNA-pulsed DCs (Fig. 5B and 5C). RNA-loaded DCs prepared from HLA-A*0201-negative donors were also unable to specifically reactivate TIL-26 cells (data not shown).

Among individual experiments, responses stimulated by DCs reached levels ranging from $20 \%-80 \%$ of those seen with stimulation by the RCC- 26 cell line. These variations in the stimulation capacity of the RNA-loaded DCs might possibly be a consequence of variations in the donor DCs that were not readily apparent from characterization of the DC phenotype. Alternatively, differences in the prevalence of epitope-specific RNA in various RNA 
A

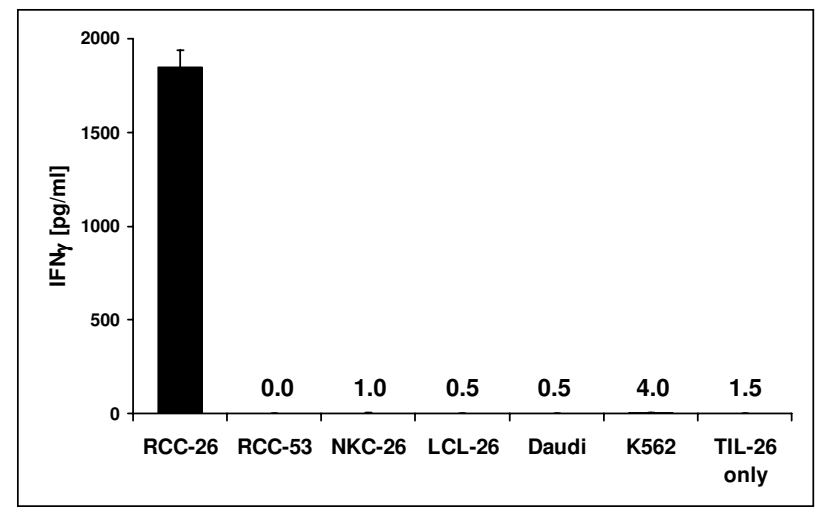

C

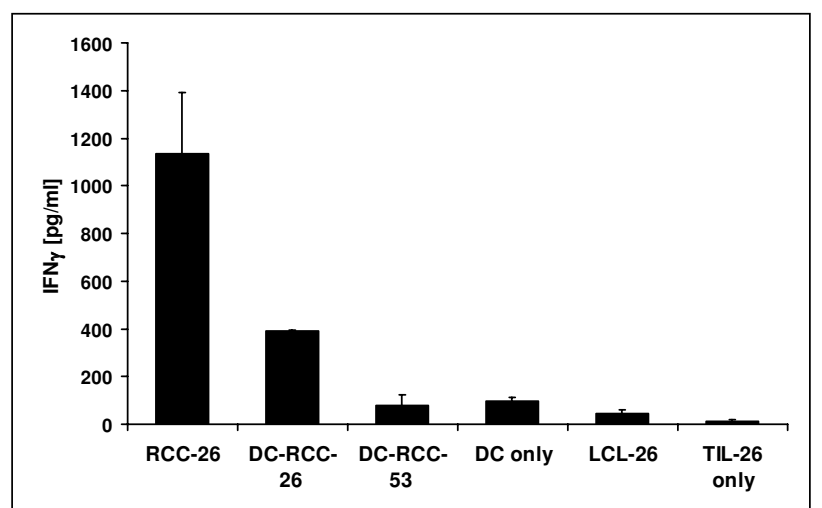

B

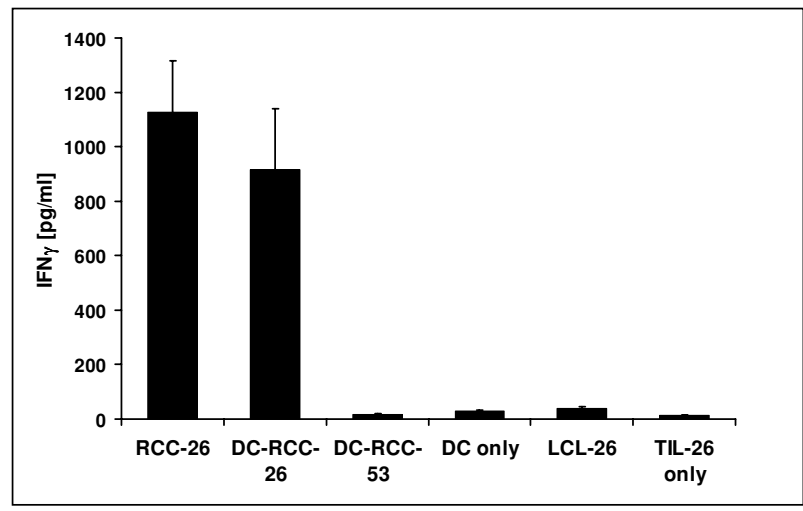

D

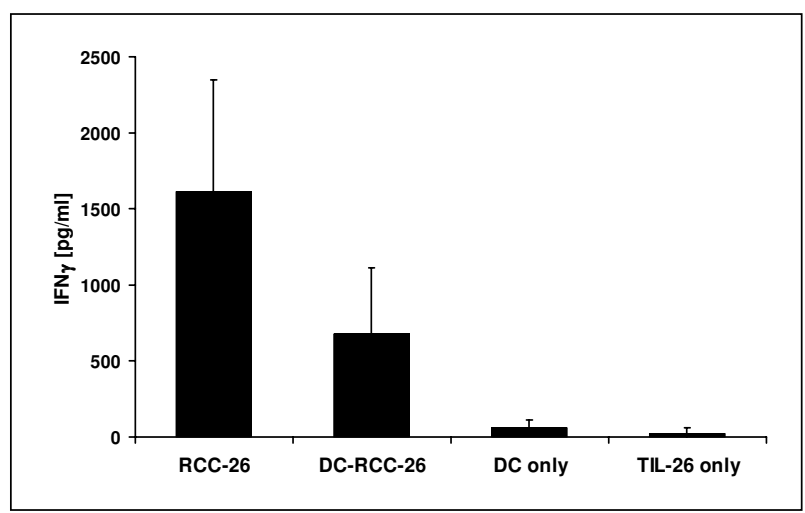

Figure 5

Reconstitution of the TIL-26 epitope in HLA-A*020 I-positive DCs after lipofection with RCC-26-derived total RNA. A) To demonstrate the specificity of TIL-26(GG) for an epitope provided by RCC-26, different tumor cell lines were co-cultivated with the $T$ cell clone in a ratio of $5: I$ and supernatants were analyzed $24 \mathrm{~h}$ later. B, C and D) HLA-A*020I-positive iDCs were transfected using DMRIE-C with total RNA derived from RCC tumor cell lines. $48 \mathrm{~h}$ after transfection and maturation the mDCs were co-cultivated with the TIL-26(GG) T cell clone at a ratio of 5:I for $24 \mathrm{~h}$. B and $\mathrm{C}$ show two individual experiments contributing to the diagram in $D$, showing pooled data for four independent experiments. All experiments were carried out in triplicates and activation of T cells was measured by analysis of IFN $\gamma$ secretion.

preparations or differences in transfection efficiencies may have contributed to these variations. In the optimal case, the TIL-26 activation capacity of RCC-26-transfected DCs was nearly as high as the stimulating potential of the RCC-26 cell line itself (Fig. 5B). Figure 5C shows another experiment in which RNA-loaded DC stimulation was only about $30 \%$ of the level of RCC- 26 cells. These data are included in Figure 5D, providing pooled results of four independent experiments.
Induction of RCC-26-specific CTL-lines using RNA-pulsed DCs

To analyze the capacity of RNA-pulsed DCs for de novo priming of antigen-specific $T$ cell responses, we generated DCs from HLA-A*0201-positive healthy donors and used them as APCs after lipofection with total RNA derived from either the RCC-26 or RCC-53 cell lines $(5.0 \mu \mathrm{g}$ RNA/ $\left.0.5 \times 10^{6} \mathrm{DCs}\right)$. Autologous PBMCs were cocultivated with the transfected mDCs in a ratio of $8: 1$ during the first round of stimulation and in a ratio of $4: 1$ thereafter. We found that DCs transfected with either RCC-26- or RCC53-derived RNA functioned as potent APCs and were able to induce RCC-26- and RCC-53-associated T cell 
A

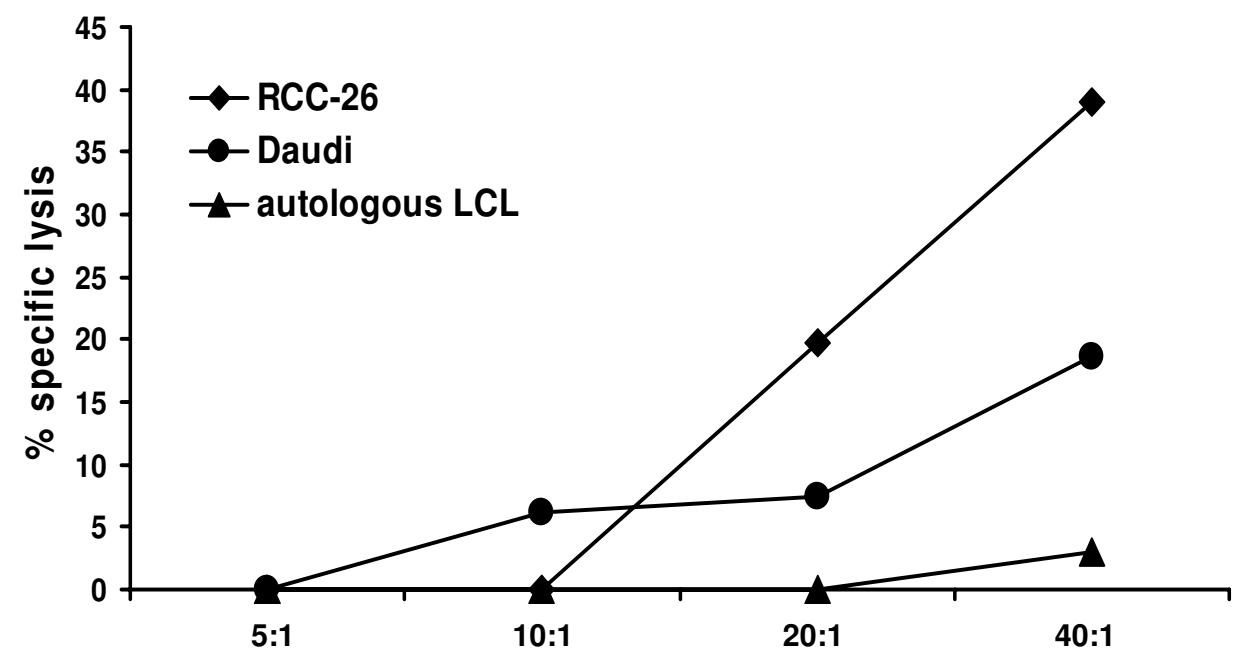

E:T ratio

B

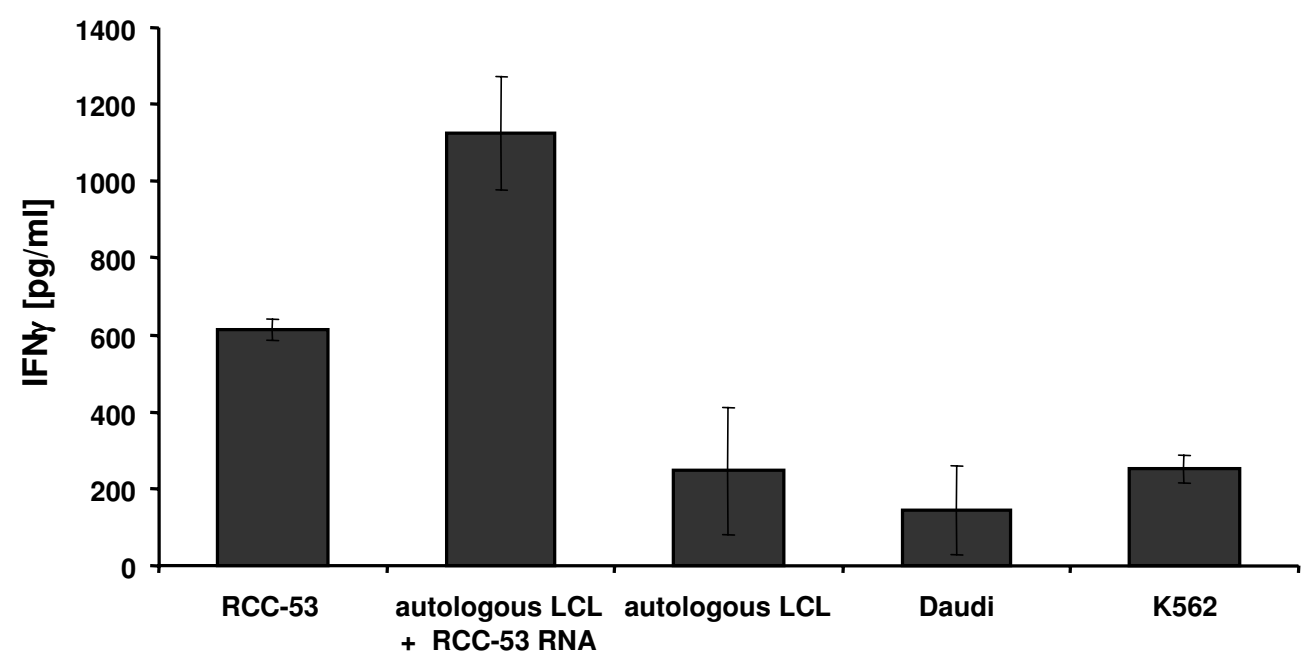

Figure 6

Induction of RCC-specific CTLs using RNA-transfected DCs as APCs. Monocyte-derived DCs were transfected with total RNA $\left(5 \mu \mathrm{g} / 0.5 \times 10^{6} \mathrm{DCs}\right)$ isolated either from RCC-26 (A) or RCC-53 (B) tumor cell lines. After a maturation period of $48 \mathrm{~h}$ the DCs were co-cultivated with autologous PBMCs (PBMC/DC ratio = 8:1) for $10-12$ days following three rounds of restimulation (PBMC/DC ratio = 4:I). In the case of RCC-53 specific CTLs (B) an additional round of restimulation was carried out using autologous LCLs transfected with RCC-53-derived total RNA. The PBMC/DC co-culture was supplemented with IL-7 and IL-2 as described in the Methods section. A) RCC-26-specific CTLs were harvested three days after the last round of restimulation and specific lysis was analyzed in a standard 4-h ${ }^{51} \mathrm{Cr}$-release assay. B) RCC-53-specific T cells were harvested 10 days after the last round of restimulation and specificity of the T cells was determined by measuring IFN $\gamma$ in the $24 \mathrm{~h}$ supernatant media T cell/target cell co-cultures $\left(\mathrm{I} .5 \times 10^{4} \mathrm{~T}\right.$ cells : $\mathrm{I} .5 \times 10^{4}$ target cells per $\left.200 \mu \mathrm{l}\right)$.

responses, respectively, after three (in the case of RCC-26) or four (in the case of RCC53) rounds of weekly restimulation (Fig. 6).
The CTL line induced with RCC-26 RNA-transfected DCs was analyzed using a $4-\mathrm{h}{ }^{51} \mathrm{Cr}$-release assay. They showed an efficient specific lysis of the RCC-26 cell line itself but 
not of autologous unloaded LCL-26 cells (Fig. 6A). Likewise, the $\mathrm{T}$ cell line primed with RCC-53-loaded RNA was activated specifically to secrete IFN $\gamma$ using either RCC53 tumor cells or autologous LCLs pulsed with RCC-53derived total RNA (Fig. 6B). Re-activation of specific T cells by RNA-transfected autologous LCLs thereby can be instrumental for analyzing specific $\mathrm{T}$ cell responses developing as a consequence of DC vaccination (Fig. 1, Step 6). In fact, it was possible to maintain the RCC-53-specific $\mathrm{T}$ cell line with autologous LCLs transfected with RCC-53derived RNA. These observations indicate that continuous preparation of DCs from patient PBMCs either for analysis of $\mathrm{T}$ cell responses or to maintain $\mathrm{T}$ cell lines ex vivo may not be required.

In both examples, Daudi and/or K562 cells were used to measure non-MHCrestricted lysis or cytokine secretion, respectively. A low level of activity was detected in the uncloned $\mathrm{T}$ cell populations but this was decidedly lower than the specific reactivation achieved using the corresponding tumor cell lines.

\section{Discussion}

In this report we present our strategy for the development of a generic RNA-pulsed DC vaccine for mRCC. Patients with mRCC have a poor prognosis and few treatment options; therefore, most clinical trials analyzing the efficacy of cell-based vaccines have studied the treatment of patients with advanced disease. A DC-based vaccine presenting RCC-associated antigens comprises a promising approach for generating antitumor responses, since DCs are the most potent antigen-presenting cells and they are capable of de novo priming of antigen-specific CD4 and CD8 effector cells from naïve T cells in vivo [reviewed in $[42,43]]$. Myeloid DCs can be generated from monocytes when cultured in the presence of GM-CSF and IL-4 ex vivo and thereby they are easily accessible in considerable numbers [44].

In contrast to melanoma where different peptide-specific vaccination approaches have been studied in numerous clinical trials, less is known about TAAs in RCC. Therefore, most clinical trials initiated to evaluate the safety and feasibility of DC-based vaccines for RCC so far have utilized DCs that were loaded with autologous tumor lysates $[17,18,45-47]$. This approach has the disadvantage that patient material must be available and often may be limited. As an alternative, two clinical trials have utilized tumor lysates prepared from established allogeneic RCC lines, which overcomes this handicap by providing a generic source of tumor cells for preparation of tumor lysates $[18,48]$. However, it is unclear how efficiently various TAAs are transferred by cell lysates. An attractive alternative is to utilize DCs transfected with defined or total tumor-derived RNA. By applying RNA, transfer of
TAAs can be quantified using surrogate marker RNA species expressed by the tumor cell lines, which is not possible when cell lysates are used [36].

A recent phase I clinical trial with mRCC patients who received immunizations with DCs expressing autologous tumor-derived RNA demonstrated the feasibility and lack of toxicity of such vaccinations [19]. In this study, the authors employed iDCs that were incubated with naked RNA on the day of administration, relying on the natural capacity of DCs to take up RNA. Based on the finding that iDCs may induce tolerance $[49,50]$, the use of mDCs would now seem to be a better strategy.

Several different methods for achieving RNA delivery to DCs have been analyzed to date, whereby electroporation and lipofection of DCs have been investigated most intensively $[19,28,30-36]$. The type of delivery that yields DCs capable of eliciting optimal T cell responses in vivo has yet to be determined. Our own studies revealed that electroporation yielded higher percentages DCs expressing protein, however, the levels of protein expression on a per cell basis were higher in lipofected DCs [36]. How these differences impact on de novo priming of $\mathrm{T}$ cells remains to be determined.

Here, we utilized DCs transfected with RCC-26-derived total RNA using the technique of lipofection. We selected the cationic lipid reagent DMRIE-C, since it provided the most efficient transfer of RNA and showed the lowest DC toxicity. We achieved a transfection rate of up to $40 \%$ when iDCs were transfected with EGFP mRNA and subsequently matured using a cytokine cocktail. It has been reported recently that comparatively high transfection efficiencies could also be obtained with other transfection reagents [34]. Here, the authors demonstrated an average transfection efficiency of $47 \%$, with a viability of $92 \%$, when mature DCs were transfected with an in vitro-transcribed EGFP RNA.

Some studies revealed that transfection with mRNA could partially activate DCs, presumably due to doublestranded secondary structures of the mRNA and toll-like receptor signalling [51-53]. Therefore, we were interested in the question whether the components used during our procedure of lipofection would influence the maturation status of the DCs. We found no evidence that application of lipid and RNA, at the concentrations used in our experiments, led to significant DC activation. Thereby, incubation with a defined pro-inflammatory cytokine cocktail was still necessary to induce a distinct mature DC phenotype. Furthermore, transfection of DCs with mRNA had no significant influence on the cytokines produced by the DCs. Thus, neither DC phenotype nor cytokine secre- 
tion levels were modulated by the lipofection components and/or procedure.

To achieve effective T cell responses in patients, DCs generated ex vivo should be competent both in re-activating pre-existing effector-memory CTLs and in priming specific $\mathrm{T}$ cells de novo. Antitumor CTL responses can often be detected in RCC patients [3-7,41]. However, these T cell responses are insufficient in disease control, possibly due to a late developing general immune suppression or due to the encounter of such T cells with defective antigen-presenting cells [54-60]. Stimulation of memory T cells with antigen-loaded DCs generated ex vivo may overcome these limitations and enhance tumor-specific T cell immunity in RCC patients.

To test whether DCs lipofected with RCC-derived RNA could reactivate specific CTLs, we used the tumor-specific T cell clone, TIL-26(GG), which is HLA-A2- restricted and specific for a TAA expressed by RCC-26 cells $[14,41]$. We could show that DCs lipofected with RCC-26-derived RNA were highly competent in reactivating these TIL-26 cells. In contrast, DCs transfected with RNA derived from RCC-53, a cell line which does not express this particular TIL-26 epitope, were unable to activate TIL-26(GG) cells, demonstrating the specificity of this response. We found that RNA-transfected DCs varied in their capacity to restimulate TIL-26 cells, often being weaker than RCC-26 tumor cells. We have shown elsewhere [36] that transferred RNA has a very short half-life in DCs so that peptides for MHC presentation will presumably only be available from one round of protein synthesis. Variations in ligand reconstitution on DCs thereby will be dependent upon the amount of RNA transferred to the DCs whereas tumor cells can generate new transcripts that can provide a continuous supply of peptides for MHC presentation.

A second important functional characteristic of RNApulsed DCs, namely their capacity to prime specific T cells de novo, was also demonstrated in our studies. We found that DCs lipofected with RCC-26- or RCC-53-derived RNAs were capable of inducing specific $T$ cell responses against the corresponding tumor cell lines. Phenotype analysis of de novo primed $\mathrm{T}$ cell populations revealed that they contained both $\mathrm{CD} 4^{+}$and $\mathrm{CD} 8^{+} \mathrm{T}$ cells. Greater expansion of $\mathrm{CD} 8^{+} \mathrm{T}$ cells occurred during restimulation, ultimately yielding altered $\mathrm{CD}^{+} / \mathrm{CD} 8^{+}$ratios when compared to naïve lymphocyte populations of healthy donors (data not shown).

Although, the in vitro-primed $\mathrm{T}$ cell lines showed some non-MHC-restricted activity directed against NK-sensitive K562 or LAK-sensitive Daudi cells, substantially stronger responses were detected against the specific tumor cell lines whose RNA was used for priming. In other studies, we demonstrated that non-MHC-restricted T cells and NK cells may play a significant role in anti-RCC immunity $[61,62]$. Therefore, we consider the induction of these innate effector cells by the DCs to be an advantage.

One critical aspect in generating and characterizing specific T cells is the need for high numbers of DCs for use as potent APCs. During the generation of the RCC-53-specific T cell line, autologous LCLs transfected with RCCderived RNA could be successfully substituted as APCs for restimulation, in addition to being used for function and specificity studies. This demonstrated that RNA-transfected LCLs could efficiently provide pMHC ligands of interest and thereby provided an easily accessible alternative to RNA-loaded DCs. However, it must be cautioned that LCLs could replace DCs only after specific $\mathrm{T}$ cell responses had developed in order to avoid reactivation of EBV-specific T cells. Cultures can be established under limiting dilutions conditions in order to separate T cells with different specificities. Alternatively, the use of miniEBV constructs that encode a limited number of EBV proteins, yet still retain the capacity to immortalize B cells, provides an elegant means to reduce this handicap [63].

A more decisive point in analyzing responses to a generic vaccine based on total tumor RNA is that autologous LCLs can provide a helpful tool for elucidating the fine specificity of T cell responses. Following loading with RNA, they can present epitopes in both class I and class II molecules. Furthermore, LCLs can be transfected with any TAA mRNA of interest in order to assess the emergence of TAAspecific T cells following vaccination. Previous clinical trials have indicated that following DC vaccination $\mathrm{T}$ cell responses could be detected against oncofetal antigen $[18,19]$, human telomerase reverse transcriptase (hTERT) [19] and G250/CA-IX antigens [19]. Transfection of LCLs with mRNA encoding these specific TAAs could be useful for evaluating specific $\mathrm{T}$ cell responses.

Two GMP-certified, genetically engineered RCC-26 cell lines, RCC-26/B7.1/IL-2 and RCC-26/B7.1/IL-7, are currently studied in phase I clinical trials $[13,23]$. These tumor cell lines could easily serve as sources of GMP-quality RNA for further development of the proposed generic DC-based vaccine approach. Findings concerning feasibility, toxicity and potential induction of autoimmunity emerging from these ongoing phase I trials will also be useful for designing a clinical trial based on RNA-loaded DCs. RNA generated from these GMP-certified RCC-26 cell lines will encode an array of TAAs present in the tumor cells. For example, both vaccine variants have been demonstrated to show over-expression of PRAME, oncofetal antigen, adipophilin and hTERT RNAs [23], all of which have been often found to be over-expressed in fresh 
tumors and to serve as targets for T cell responses $[11,18$ $21,64,65]$. The immune monitoring tools specific for such molecules that prove useful for defining $\mathrm{T}$ cell responses that develop following tumor cell vaccination also can be used for analyzing specific $T$ cell responses to the generic DC-based vaccine proposed here. As more information emerges regarding specific TAAs that can be used to target immune responses to RCC, it will be possible to develop defined vaccines based on the use of pools of RNA encoding selected TAAs. Such an approach has recently been described for melanoma [35].

\section{Conclusion}

We describe a DC-based vaccine strategy for RCC patients using a generic source of RNA derived from a well characterized tumor cell line. When DCs derived from HLA-A2positive donors were loaded with tumor cell line-derived RNA using the method of lipofection, they were able to reactivate effector-memory CTLs and were also capable of priming $\mathrm{T}$ cells de novo to mediate cytotoxicity or secrete cytokine after contact with RCC cells. The availability of GMP-certified cells, expressing a variety of TAAs that are shared by many RCC and can provide target epitopes for T cells will allow this strategy to be more easily adapted for clinical testing. Furthermore, the ability to load tumor cell line-derived RNA into autologous LCLs provides a useful tool for immune monitoring.

\section{Competing interests}

The author(s) declare that they have no competing interests.

\section{Authors' contributions}

CG and SR developed the RNA-loaded DCs and performed the functional studies, they analyzed the data and drafted the manuscript.

AW carried out the experiments using RNA-loaded DCs for de novo priming of T cells.

EN provided the TIL-26(GG) cells for assessment of effector-memory $\mathrm{T}$ cell responses.

DJS established the RCC and TIL lines, conceived the vaccine strategy, participated in the design and analysis of the experiments and helped to draft the manuscript.

\section{All authors read and approved the final manuscript.}

\section{Acknowledgements}

This work was supported by grants of the German Research Council (SFB 455 ) and the 6th European Framework Programme (,Allostem” LSHB-CT2004-5033 19). We thank Miran Javorovic for advice on the preparation of in vitro-transcribed RNA, Anke Zobywalski for suggestions on DC phenotyping and Sabine Eichenlaub and Anna Brandl for excellent technical assistance.

\section{References}

I. Motzer RJ: Renal cell carcinoma: a priority malignancy for development and study of novel therapies. J Clin Oncol 2003, 2 I : I 193-4.

2. Kim HL, Belldegrun AS, Figlin RA: Immune gene therapy for kidney cancer: the search for a magic trigger. Mol Ther 2003, 7:I53-4.

3. Schendel DJ, Oberneder R, Falk CS, Jantzer P, Kressenstein S, Maget B, Hofstetter A, Riethmuller G, Noessner E: Cellular and molecular analyses of MHC-restricted and non-MHC-restricted effector cells recognizing renal cell carcinomas: problems and perspectives for immunotherapy. J Mol Med 1997, 75:400-13.

4. Pierce WC, Belldegrun A, Figlin RA: Cellular therapy: Scientific rationale and clinical results in the treatment of renal cell carcinoma. Semin Oncol 1995, 22:74-80.

5. Spiess PJ, Yang JC, Rosenberg SA: In vivo antitumor activity of tumor-infiltrating lymphocytes expanded in recombinant interleukin-2. J Natl Cancer Inst 1987, 79:1067-1075.

6. Bukowski RM, Sharfman W, Murthy S, Rayman P, Tubbs R, Alexander J, Budd GT, Sergi JS, Bauer L, Gibson V: Clinical results and characterization of tumor-infiltrating lymphocytes with or without recombinant interleukin-2 in human metastatic renal cell carcinoma. Cancer Res 1991, 51:4199-4205.

7. Merrouche Y, Bain C, Combaret V, Mercatello A, Coronel B, Moskovtchenko JF, Tolstoshev P, Moen R, Philip T: Clinical application of retroviral gene transfer in oncology: Results of a French study with tumor infiltrating lymphocytes transduced with the gene of resistance to neomycin. J Clin Oncol 1995, 13:410-418.

8. Van den Eynde BJ, van der Bruggen P: $\mathbf{T}$ cell defined tumor antigens. Curr Opin Immunol 1997, 9:684-93.

9. Novellino L, Castelli C, Parmiani G: A listing of human tumor antigens recognized by $T$ cells: March 2004 update. Cancer Immunol Immunother 2005, 54: I87-207.

10. Jungbluth AA, Chen YT, Stockert E, Busam KJ, Kolb D, Iversen K, Coplan K, Williamson B, Altorki N, Old LJ: Immunohistochemical analysis of NY-ESO-I antigen expression in normal and malignant human tissues. Int J Cancer 200I, 92:856-60.

II. Neumann E, Engelsberg A, Decker J, Storkel S, Jaeger E, Huber C, Seliger B: Heterogeneous expression of the tumor-associated antigens RAGE-I, PRAME, and glycoprotein 75 in human renal cell carcinoma: candidates for T-cell-based immunotherapies? Cancer Res 1998, 58:4090-5.

12. Coral S, Sigalotti L, Altomonte M, Engelsberg A, Colizzi F, Cattarossi I, Maraskovsky E, Jager E, Seliger B, Maio M: 5-aza-2'-deoxycytidine-induced expression of functional cancer testis antigens in human renal cell carcinoma: immunotherapeutic implications. Clin Cancer Res 2002, 8:2690-5.

13. Frankenberger B, Regn S, Geiger C, Noessner E, Falk CS, Pohla H, Javorovic M, Silberzahn T, Wilde S, Buchner A, Siebels M, Oberneder R, Willimsky G, Pezzutto A, Blankenstein T, Schendel DJ: Cell-based vaccines for renal cell carcinoma: Genetically-engineered tumor cells and monocyte-derived dendritic cells. World J Urol 2005, 23(3): 166-174.

14. Schendel DJ, Gansbacher B, Oberneder R, Kriegmair M, Hofstetter A, Riethmuller G, Segurado OG: Tumor-specific lysis of human renal cell carcinomas by tumor-infiltrating lymphocytes. I. HLA-A2-restricted recognition of autologous and allogeneic tumor lines. J Immunol 1993, I 5 I:4209-4220.

15. Brossart P, Stuhler G, Flad T, Stevanovic S, Rammensee HG, Kanz L, Brugger W: Her-2/neu-derived peptides are tumor-associated antigens expressed by human renal cell and colon carcinoma lines and are recognized by in vitro induced specific cytotoxic T lymphocytes. Cancer Res 1998, 58:732-736.

16. Heiser A, Maurice MA, Yancey DR, Coleman DM, Dahm P, Vieweg J: Human dendritic cells transfected with renal RNA stimulate polyclonal $\mathrm{T}$-cell responses against antigens expressed by primary and metastatic tumors. Cancer Res 200 I, 6 I:3388-3393.

17. Kurokawa T, Oelke M, Mackensen A: Induction and clonal expansion of tumor-specific cytotoxic $T$ lymphocytes from renal cell carcinoma patients after stimulation with autologous dendritic cells loaded with tumor cells. Int J Cancer 2001, 91:749-756.

18. Höltl L, Zelle-Reiser C, Gander H, Papesh C, Ramoner R, Bartsch G, Rogatsch H, Barsoum AL, Coggin JH Jr, Thurnher M: Immuno- 
therapy of metastatic renal cell carcinoma with tumor lysate-pulsed autologous dendritic cells. Clin Cancer Res 2002, 8:3369-3376.

19. Su Z, Dannull J, Reiser A, Yancey D, Pruitt S, Madden J, Coleman D, Niedzwiecki D, Gilboa E, Vieweg J: Immunological and clinical responses in metastatic renal cancer patients vaccinated with tumor RNA-transfected dendritic cells. Cancer Res 2003, 63:2127-2133.

20. Grunebach F, Muller MR, Nencioni A, Brossart P: Delivery of tumor-derived RNA for the induction of cytotoxic T-lymphocytes. Gene Ther 2003, 10:367-76.

21. Weinschenk T, Gouttefangeas C, Schirle M, Obermayr F, Walter S, Schoor O, Kurek R, Loeser W, Bichler KH, Wernet D, Stevanovic S, Rammensee HG: Integrated functional genomics approach for the design of patient-individual antitumor vaccines. Cancer Res 2002, 62:5818-5827.

22. Pantuck AJ, Zeng G, Belldegrun A, Figlin RA: Pathobiology, prognosis, and targeted therapy for renal cell carcinoma: Exploiting the hypoxia-induced pathway. Clin Cancer Res 2003, 9:464l-52.

23. Frankenberger B, Pohla H, Noessner E, Willimsky G, Papier B, Pezzutto A, Kopp J, Oberneder R, Blankenstein T, Schendel DJ: Influence of CD80, interleukin-2 and interleukin-7 expression in human renal cell carcinoma on the expansion, function, and survival of tumor-specific CTLs. Clin Cancer Res 2005, I I:I733-1742.

24. Gilboa E, Vieweg J: Cancer immunotherapy with mRNA-transfected dendritic cells. Immunol Reviews 2004, 199:25 I-263.

25. Djafarzadeh R, Noessner E, Schendel DJ, Notohamiproto M, von Lüttichau I, Nelson PJ: GPI-anchored TIMP-I treatment renders renal cell carcinoma sensitive to FAS meditated killing. in press.

26. Schendel DJ, Frankenberger B, Jantzer P, Cayeux S, Noessner E, Willimsky G, Maget B, Pohla H, Blankenstein T: Expression of B7.I (CD80) in a renal cell carcinoma line allows expansion of tumor-associated cytotoxic $T$ lymphocytes in the presence of an alloresponse. Gene Ther 2000, 7:2007-20I4.

27. Jonuleit H, Kuhn U, Muller G, Steinbrink K, Paragnik L, Schmitt E, Knop J, Enk AH: Pro-inflammatory cytokines and prostaglandins induce maturation of potent immunostimulatory dendritic cells under fetal calf serum-free conditions. Eur J Immunol |997, 27:3|35-3|42.

28. Nair SK, Boczkowski D, Morse M, Cumming RI, Lyerly HK, Gilboa E: Induction of primary carcinoembryonic antigen (CEA)-specific cytotoxic $\mathrm{T}$ lymphocytes in vitro using human dendritic cells transfected with RNA. Nat Biotechnol 1998, 1 6:364-369.

29. Falk CS, Nossner E, Frankenberger B, Schendel DJ: Non-MHCrestricted CD4+ T lymphocytes are regulated by HLA-Cw7mediated inhibition. Hum Immunol 2000, 6 I (I 2): I2 I9-32.

30. Boczkowski D, Nair SK, Snyder D, Gilboa E: Dendritic cells pulsed with RNA are potent antigen-presenting cells in vitro and in vivo. J Exp Med 1996, I 84:465-472.

31. Van Tendeloo VF, Ponsaerts P, Lardon F, Nijs G, Lenjou M, Van Broeckhoven C, Van Bockstaele DR, Berneman ZN: Highly efficient gene delivery by mRNA electroporation in human hematopoietic cells: superiority to lipofection and passive pulsing of mRNA and to electroporation of plasmid cDNA for tumor antigen loading of dendritic cells. Blood 2001, 98:49-56.

32. Heiser A, Coleman D, Dannull J, Yancey D, Maurice MA, Lallas CD, Dahm P, Niedzwiecki D, Gilboa E, Vieweg J: Autologous dendritic cells transfected with prostate-specific antigen RNA stimulate CTL responses against metastatic prostate tumors. J Clin Invest 2002, 109:409-4I7.

33. Bonehill A, Heirman C, Tuyaerts S, Michiels A, Breckpot K, Brasseur F, Zhang Y, Van Der Bruggen P, Thielemans K: Messenger RNAelectroporated dendritic cells presenting MAGE-A3 simultaneously in HLA class I and class II molecules. J Immunol 2004, I 72:6649-6657.

34. Liao X, Li Y, Bonini C, Nair S, Gilboa E, Greenberg PD, Yee C: Transfection of RNA encoding tumor antigens following maturation of dendritic cells leads to prolonged presentation of antigen and the generation of high-affinity tumor-reactive cytotoxic T lymphocytes. Mol Ther 2004, 9:757-764.

35. Schaft N, Dorrie J, Thumann P, Beck VE, Muller I, Schultz ES, Kampgen E, Dieckmann D, Schuler G: Generation of an optimized polyva- lent monocyte-derived dendritic cell vaccine by transfecting defined RNAs after rather than before maturation. J Immunol 2005, I 74:3087-3097.

36. Javorovic M, Pohla H, Frankenberger B, Wölfel T, Schendel DJ: RNA transfer by electroporation into mature dendritic cells leading to reactivation of effector-memory cytotoxic $T$ lymphocytes: a quantitative analysis. Mol Ther 2005 in press.

37. Sallusto $F$, Lanzavecchia A: Understanding dendritic cell and $\mathbf{T}$ lymphocyte traffic through the analysis of chemokine receptor expression. Immunol Rev 2000, I77:134-|40.

38. Sozzani S, Allavena P, Vecchi A, Mantovani A: Chemokines and dendritic cell traffic. J Clin Immunol 2000, 20:|5|-|60.

39. Luft T, Jefford M, Luetjens P, Toy T, Hochrein H, Masterman KA, Maliszewski C, Shortman K, Cebon J, Maraskovsky E: Functionally distinct dendritic cell (DC) populations induced by physiologic stimuli: prostaglandin $\mathrm{E}(2)$ regulates the migratory capacity of specific DC subsets. Blood 2002, I 00: I 362-I372.

40. Scandella E, Men Y, Gillessen S, Forster R, Groettrup M: Prostaglandin E2 is a key factor for CCR7 surface expression and migration of monocyte-derived dendritic cells. Blood 2002, 100:|354-136|.

4I. Jantzer P, Schendel DJ: Human renal cell carcinoma antigenspecific CTLs: antigen-driven selection and long-term persistence in vivo. Cancer Res 1998, 58:3078-3086.

42. Steinman RM, Dhodapkar M: Active immunization against cancer with dendritic cells: the near future. Int J Cancer 200I, 94:459-473.

43. Banchereau J, Palucka AK: Dendritic cells as therapeutic vaccines against cancer. Nat Rev Immunol 2005, 5:296-306.

44. Romani N, Gruner S, Brang D, Kampgen E, Lenz A, Trockenbacher B, Konwalinka G, Fritsch PO, Steinman RM, Schuler G: Proliferating dendritic cell progenitors in human blood. J Exp Med 1994, 180:83-93.

45. Marten A, Flieger D, Renoth S, Weineck S, Albers P, Compes $M$, Schottker B, Ziske C, Engelhart S, Hanfland P, Krizek L, Faber C, von Ruecker A, Muller S, Sauerbruch T, Schmidt-Wolf IG: Therapeutic vaccination against metastatic renal cell carcinoma by autologous dendritic cells: preclinical results and outcome of a first clinical phase I/II trial. Cancer Immunol Immunother 2002, 5 I:637-644.

46. Oosterwijk-Wakka JC, Tiemessen DM, Bleumer I, de Vries IJ, Jongmans W, Adema G], Debruyne FM, de Mulder PH, Oosterwijk E, Mulders PF: Vaccination of patients with metastatic renal cell carcinoma with autologous dendritic cells pulsed with autologous tumor antigens in combination with interleukin-2: a phase I study. J Immunother 2002, 25:500-508.

47. Gitlitz BJ, Belldegrun AS, Zisman A, Chao DH, Pantuck AJ, Hinkel A, Mulders $\mathrm{P}$, Moldawer N, Tso CL, Figlin RA: A pilot trial of tumor lysate-loaded dendritic cells for the treatment of metastatic renal cell carcinoma. J Immunother 2003, 26:4I2-4I9.

48. Pandha HS, John RJ, Hutchinson J, James N, Whelan M, Corbishley C, Dalgleish AG: Dendritic cell immunotherapy for urological cancers using cryopreserved allogeneic tumour lysatepulsed cells: a phase I/II study. Br J Urol 2004, 94:4I 2-4I8.

49. Lutz MB, Schuler G: Immature, semi-mature and fully mature dendritic cells: which signals induce tolerance or immunity? Trends Immunol 2002, 23:445-449.

50. Steinman RM, Nussenzweig MC: Avoiding horror autotoxicus: the importance of dendritic cells in peripheral $T$ cell tolerance. Proc Natl Acad Sci USA 2002, 99:35I-358.

5I. Ni H, Capodici J, Cannon G, Communi D, Boeynaems JM, Kariko K, Weissman D: Extracellular mRNA induces dendritic cell activation by stimulating tumor necrosis factor-alpha secretion and signaling through a nucleotide receptor. J Biol Chem 2002, 277: $12689-12696$.

52. Ceppi M, Ruggli N, Tache V, Gerber H, McCullough KC, Summerfield $A$ : Double-stranded secondary structures on mRNA induce type I interferon (IFN alpha/beta) production and maturation of mRNA-transfected monocyte-derived dendritic cells. J Gene Med 2005, 7:452-465.

53. Sen GC, Sarkar SN: Transcriptional signaling by doublestranded RNA: role of TLR3. Cytokine Growth Factor Rev 2005, I6: I- I4.

54. Thurnher M, Radmayr C, Ramoner R, Ebner S, Bock G, Klocker H, Romani N, Bartsch G: Human renal-cell carcinoma tissue contains dendritic cells. Int J Cancer 1996, 68:1-7. 
55. Troy AJ, Summers KL, Davidson PJ, Atkinson CH, Hart DN: Minimal recruitment and activation of dendritic cells within renal cell carcinoma. Clin Cancer Res 1998, 4:585-593.

56. Schwaab T, Schned AR, Heaney JA, Cole BF, Atzpodien J, Wittke F, Ernstoff MS: In vivo description of dendritic cells in human renal cell carcinoma. J Urol 1999, 162:567-573.

57. Almand B, Resser JR, Lindman B, Nadaf S, Clark JI, Kwon ED, Carbone DP, Gabrilovich DI: Clinical significance of defective dendritic cell differentiation in cancer. Clin Cancer Res 2000, 6: I755-1766.

58. Ahmad M, Rees RC, Ali SA: Escape from immunotherapy: possible mechanisms that influence tumor regression/progression. Cancer Immunol Immunother 2004, 53:844-854.

59. Khong HT, Wang QJ, Rosenberg SA: Identification of multiple antigens recognized by tumor-infiltrating lymphocytes from a single patient: tumor escape by antigen loss and loss of MHC expression. J Immunother 2004, 27: I 84- 190.

60. Menetrier-Caux C, Montmain G, Dieu MC, Bain C, Favrot MC, Caux $C$, Blay JY: Inhibition of the differentiation of dendritic cells from CD34(+) progenitors by tumor cells: role of interleukin-6 and macrophage colony-stimulating factor. Blood |998, 92:4778-91.

61. Falk CS, Noessner E, Weiss EH, Schendel DJ: Retaliation against tumor cells showing aberrant HLA expression using lymphokine activated killer-derived T cells. Cancer Res 2002, 62:480-487.

62. Schleypen JS, Von Geldern M, Weiss EH, Kotzias N, Rohrmann K, Schendel DJ, Falk CS, Pohla H: Renal cell carcinoma-infiltrating natural killer cells express differential repertoires of activating and inhibitory receptors and are inhibited by specific HLA class I allotypes. Int J Cancer 2003, 106:905-912.

63. Moosmann A, Khan N, Cobbold M, Zentz C, Delecluse HJ, Hollweck G, Hislop AD, Blake NW, Croom-Carter D, Wollenberg B, Moss PA, Zeidler R, Rickinson AB, Hammerschmidt W: B cells immortalized by a mini-Epstein-Barr virus encoding a foreign antigen efficiently reactivate specific cytotoxic T cells. Blood 2002, 100:1755-1764.

64. Schmidt SM, Schag K, Muller MR, Weinschenk T, Appel S, Schoor O, Weck MM, Grunebach F, Kanz L, Stevanovic S, Rammensee HG, Brossart P: Induction of adipophilin-specific cytotoxic T lymphocytes using a novel HLA-A2-binding peptide that mediates tumor cell lysis. Cancer Res 2004, 64: I I 64- I I 70.

65. Sievers E, Albers P, Schmidt-Wolf IG, Marten A: Telomerase pulsed dendritic cells for immunotherapy for renal cell carcinoma. J Urol 2004, I7 I: I I4-1 I9.

\section{Publish with Bio Med Central and every scientist can read your work free of charge}

"BioMed Central will be the most significant development for disseminating the results of biomedical research in our lifetime. "

Sir Paul Nurse, Cancer Research UK

Your research papers will be:

- available free of charge to the entire biomedical community

- peer reviewed and published immediately upon acceptance

- cited in PubMed and archived on PubMed Central

- yours - you keep the copyright

Submit your manuscript here:

http://www.biomedcentral.com/info/publishing_adv.asp
BioMedcentral 